\title{
Optimizing the morphology of metal multilayer films for indium tin oxide (ITO)-free inverted organic solar cells
}

\author{
Jan Meiss, ${ }^{\text {a) }}$ Moritz K. Riede, and Karl Leo \\ Institut für Angewandte Photophysik, Technische Universität Dresden, D-01062 Dresden, Germany
}

(Received 21 January 2009; accepted 14 February 2009; published online 25 March 2009)

\begin{abstract}
We present metal multilayers consisting of aluminum and silver in different combinations serving as semitransparent top contacts for organic solar cells. Scanning electron microscopy, atomic force microscopy, and optical spectroscopy are used to illustrate how ultrathin $\mathrm{Al}$ interlayers influence the morphology of Ag layers evaporated on top of organic materials and how closed layers with good conductivity can be achieved. Multilayer metal contacts are used to fabricate top-illuminated small-molecule organic solar cells (SM-OSCs) which reach efficiencies comparable to conventional SM-OSCs that employ tin-doped indium oxide as electrode. It is shown that combinations of $\mathrm{Al}$ and $\mathrm{Au}$ lead to similar results, suggesting a similar mechanism for the influence on morphological development of both Ag and Au. (C) 2009 American Institute of Physics. [DOI: 10.1063/1.3100039]
\end{abstract}

\section{INTRODUCTION}

Since the first report of a flat heterojunction smallmolecule organic solar cell (SM-OSC) by Tang, ${ }^{1}$ this promising new field has attracted considerable interest, leading to new concepts like bulk heterojunctions, ${ }^{2}$ intentional doping of organic matrices with donor or acceptor molecules, ${ }^{3}$ the $p-i-n$ architecture, ${ }^{4}$ or tandem cells with efficiencies of over $5 \%{ }^{5}$

While SM-OSCs currently have lower efficiencies compared to polymer-based ${ }^{6-8}$ organic solar cells, they involve no wet-chemical processes and are expected to be well suited for mass production by vacuum evaporation, as has been demonstrated for small-molecule organic light-emitting diodes (OLEDs).

Due to the extremely low material consumption in the order of $\approx 1 \mathrm{~g} / \mathrm{m}^{2}$ (total device thickness of $<1 \mu \mathrm{m}$ ) and the resulting low price, SM-OSCs are interesting for niche markets where cost-efficient, lightweight, and flexible solutions are advantageous, e.g., small consumer electronics or small-scale current generation in remote areas. Given time, SM-OSCs are expected be competitive to inorganic and other organic solar cells due to weight, price, and ease of installation.

Currently, in research and development of thin-film optoelectronic devices like OLED and SM-OSC, the standard substrate configuration involves a glass substrate coated with a prestructured electrode of tin-doped indium oxide $\left[\mathrm{In}_{2} \mathrm{O}_{3}: \mathrm{Sn}\right.$ (ITO)]. ITO is typically deposited in a sputter process and provides an excellent combination of transparency and conductivity. At the same time, there are also disadvantages: it is brittle which inhibits its use in flexible devices; the recent increase in demand for indium, e.g., for flat panel displays and high-technology applications, led to rising prices in the past decade; if devices like inverted SMOSC or OLED deposited on a nonopaque substrate, illuminated or emitting light through the top, are to be fabricated,

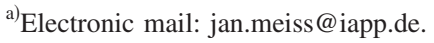

ITO is difficult to apply since sputtering onto organic layers can damage the organic materials underneath.

These issues are widely recognized, and an increasing effort is being made to test alternative transparent conductive materials for SM-OSC and OLED, e.g., aluminum-doped zinc oxide, ${ }^{10}$ carbon nanotubes for polymer-based solar cells, ${ }^{11,12}$ conductive polymers, ${ }^{13,14}$ metals, ${ }^{15-17}$ solutionprocessed graphene,${ }^{18}$ or nanowire mesh arrays. ${ }^{19}$ It is noteworthy that several of these alternatives require wetchemical or sputtering steps that cannot be easily incorporated into a SM-OSC production process. In contrast, metal layers can be thermally evaporated in vacuum and can be deposited in the same inline system as the organic small molecules.

Here, we introduce multilayer thin metal films that can be used as a transparent electrode for SM-OSC and that can be tailored to suit specific demands. It is illustrated by micrographs how the morphology of Ag films having good optical properties can be modified by employing ultrathin Al surfactant layers. Four solar cell samples employing Ag and $\mathrm{Au}$ with and without an $\mathrm{Al}$ intermediate layer are characterized, showing how device performance can be greatly increased by using the surfactant.

\section{EXPERIMENTAL}

All samples are fabricated using shadow masks in a custom-made vacuum system (K.J. Lesker, UK) at a base pressure of $10^{-6}$ mbar and in a custom-made multichamber ultrahigh vacuum evaporation system (BESTEC, Germany) at a base pressure of $10^{-8}$ mbar. Float glass precleaned with detergents and organic solvents followed by oxygen plasma treatment is used as a substrate.

For solar cells, the layer sequence is illustrated in Fig. 1. The preparation is performed as follows: A metal back contact of $100 \mathrm{~nm} \mathrm{Al}$ is deposited, followed by $1 \mathrm{~nm}$ of a proprietary $p$-type dopant (Novaled AG, Dresden, Germany). ${ }^{20}$ As a hole transporting material, $30 \mathrm{~nm}$ of 10 wt $\% \quad p$-doped $4,4^{\prime}, 4^{\prime \prime}$-tris(1-naphthylphenylamino)triphenylamine (TNATA) is used. As a light absorbing mate- 


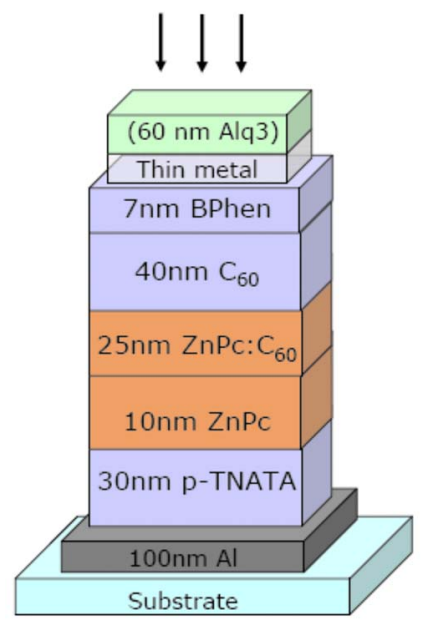

FIG. 1. (Color online) Solar cell stack. Omitted is the $1 \mathrm{~nm}$ NDP2 for better hole extraction between $100 \mathrm{~nm} \mathrm{Al}$ and $30 \mathrm{~nm} p$-TNATA. For samples created for morphological studies, the $60 \mathrm{~nm} \mathrm{Alq}_{3}$ are not included so that the thin metal contact could directly be examined.

rial, layers of zinc phthalocyanine $(\mathrm{ZnPc})(10 \mathrm{~nm})$ and coevaporated $\mathrm{ZnPc}: \mathrm{C}_{60}(25 \mathrm{~nm}$, ratio of $1: 1)$ are deposited. After an additional absorber/transport layer of $\mathrm{C}_{60}(40 \mathrm{~nm}), 7$ $\mathrm{nm}$ of 4,7-diphenyl-1,10-phenanthroline (BPhen) is used as an exciton blocker. All materials except the dopants had been purified at least twice by vacuum gradient sublimation. Different thicknesses and combinations of $\mathrm{Al} / \mathrm{Ag}$ and $\mathrm{Al} / \mathrm{Au}$ (6-17 $\mathrm{nm}$ total thickness) are used as a transparent top contact. On top of the metal electrode, $60 \mathrm{~nm}$ of tris(8-hydroxyquinolinato)-aluminum $\left(\mathrm{Alq}_{3}\right)$ increase light outcoupling from the solar cell. ${ }^{16,21}$ Typical SM-OSC sizes are $\approx 6.7 \mathrm{~mm}^{2}$ measured using an optical microscope.

The samples for morphology examination have the same structure as the solar cells, except that no shadow masks are used and the $\mathrm{Alq}_{3}$ capping layer is not evaporated onto the metal contact, which would make it impossible to study the metal surface.

Sixteen samples are made on the same substrate in one run. This way, the only variations are for the top contact while keeping the deposition conditions for all other layers (hole transport layer, absorber, electron transport layer, where applicable capping layer) constant. Additional singlelayer samples are made on $6.25 \mathrm{~cm}^{2}$ precleaned float glass to study the properties of single $\mathrm{Al}$ and $\mathrm{Ag}$ layers without underlying organic materials.

The completed solar cells are encapsulated using glass and epoxy in a glovebox attached to the vacuum deposition chamber under nitrogen atmosphere, then stored at ambient conditions. $J(V)$-characteristics are recorded using a source measurement unit 236 SMU (Keithley) under an AM 1.5g sun simulator (Hoenle AG), monitored with a silicon photodiode with respect to which intensities are given. The $J(V)$-data are not corrected for spectral mismatch. Previous experiments with similar devices suggest that the mismatch is close to unity due to the combination of the spectrum of the sun simulator and the $\mathrm{ZnPc}: \mathrm{C}_{60}$ absorber system.

Reflection and transmission measurements are performed on a Lambda $900 \mathrm{UV} / \mathrm{VIS} / \mathrm{NIR}$ spectrometer (Perkin Elmer) (not shown). The morphology of deposited top con-
TABLE I. Solar cell characteristics.

\begin{tabular}{lcccc}
\hline \hline Metal contact & $\begin{array}{c}J_{\mathrm{SC}} \\
\left(\mathrm{mA} / \mathrm{cm}^{2}\right)\end{array}$ & $\begin{array}{c}V_{\mathrm{OC}} \\
(\mathrm{V})\end{array}$ & $\begin{array}{c}\mathrm{FF} \\
(\%)\end{array}$ & $\begin{array}{c}\eta \\
(\%)\end{array}$ \\
\hline $16 \mathrm{~nm} \mathrm{Ag}$ & 7.28 & 0.460 & 41.03 & 1.37 \\
$1 \mathrm{~nm} \mathrm{Al}, 14 \mathrm{~nm} \mathrm{Ag}$ & 7.02 & 0.529 & 56.21 & 2.09 \\
$10 \mathrm{~nm} \mathrm{Au}$ & 6.88 & 0.510 & 32.21 & 1.13 \\
$1 \mathrm{~nm} \mathrm{Al}, 10 \mathrm{~nm} \mathrm{Au}$ & 6.86 & 0.522 & 53.31 & 1.91 \\
\hline \hline
\end{tabular}

tacts and single metal layers is analyzed using tapping mode atomic force microscopy (AFM) (Nanoscope, Digital Instruments) and scanning electron microscopy (SEM) (Zeiss DSM 982 Gemini). For AFM, great care is taken to ensure reproducibility by measuring several spots on the sample on several days using different tips ( $n$-type $\mathrm{Si}$ tip, typical tip radius of $10 \mathrm{~nm}$, backside $\mathrm{Al}$ coated).

\section{RESULTS}

\section{A. Solar cells}

Prior to morphological investigation, four different SMOSCs are created. To study the role of the Al surfactant and the influence of the electrode structure, the chosen electrical contacts are (I) $16 \mathrm{~nm} \mathrm{Ag}$, (II) $1 \mathrm{~nm} \mathrm{Al} / 14 \mathrm{~nm} \mathrm{Ag}$, (III) 10 $\mathrm{nm} \mathrm{Au}$, and (IV) $1 \mathrm{~nm} \mathrm{Al} / 10 \mathrm{~nm} \mathrm{Au} .16 \mathrm{~nm} \mathrm{Ag}$ is chosen instead of $14 \mathrm{~nm} \mathrm{Ag}$ because with the current set of deposition parameters, $14 \mathrm{~nm}$ is just below the coalescence threshold and yields no efficiently operational devices, while 16 $\mathrm{nm}$ is sufficient for efficient conduction.

The solar cell characteristics are summarized in Table I; the $J(V)$ characteristics are shown in Fig. 2 (under illumination) and Fig. 3 (in the dark). All current densities are normalized to a light intensity of $100 \mathrm{~mW} / \mathrm{cm}^{2}$. It can be seen that SM-OSCs (II) and (IV) have similar open-circuit voltages $V_{\mathrm{OC}}$ of 0.522 and $0.529 \mathrm{~V}$, respectively, which shows that the type of metal ( $\mathrm{Au}$ or $\mathrm{Ag}$ ) has little influence on the voltage in the presence of $1 \mathrm{~nm} \mathrm{Al}$. While the bulk work functions differ by $\approx 0.8 \mathrm{eV}$, assuming $4.3 \mathrm{eV}$ for $\mathrm{Ag}$ and 5.1

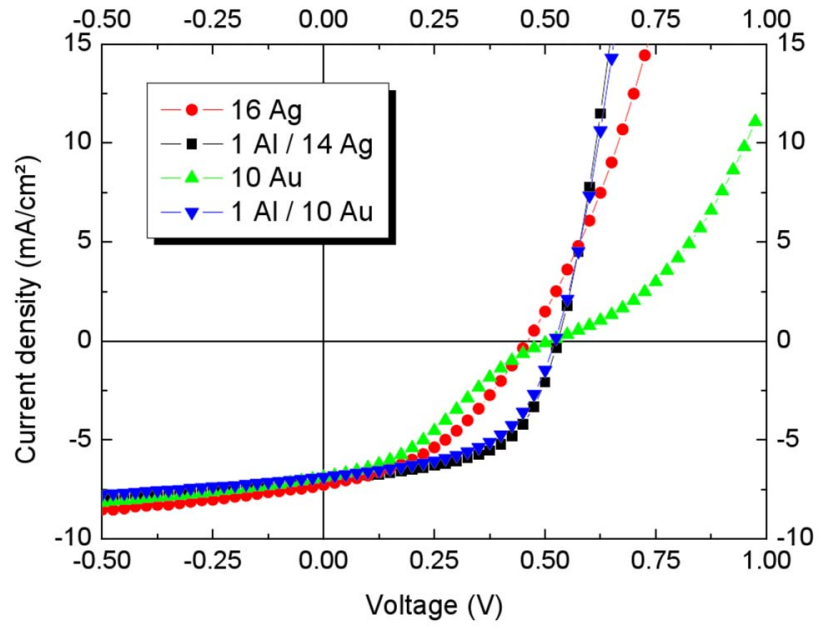

FIG. 2. (Color online) $J(V)$-characteristics under illumination of different solar cells with top contacts of (I) $16 \mathrm{~nm} \mathrm{Ag}$ (circles), (II) $1 \mathrm{~nm} \mathrm{Al} / 14 \mathrm{~nm} \mathrm{Ag}$ (squares), (III) $10 \mathrm{~nm} \mathrm{Au} \mathrm{(triangles),} \mathrm{and} \mathrm{(IV)} 1 \mathrm{~nm} \mathrm{Al} / 10 \mathrm{~nm} \mathrm{Au}$ (upsidedown triangles). 


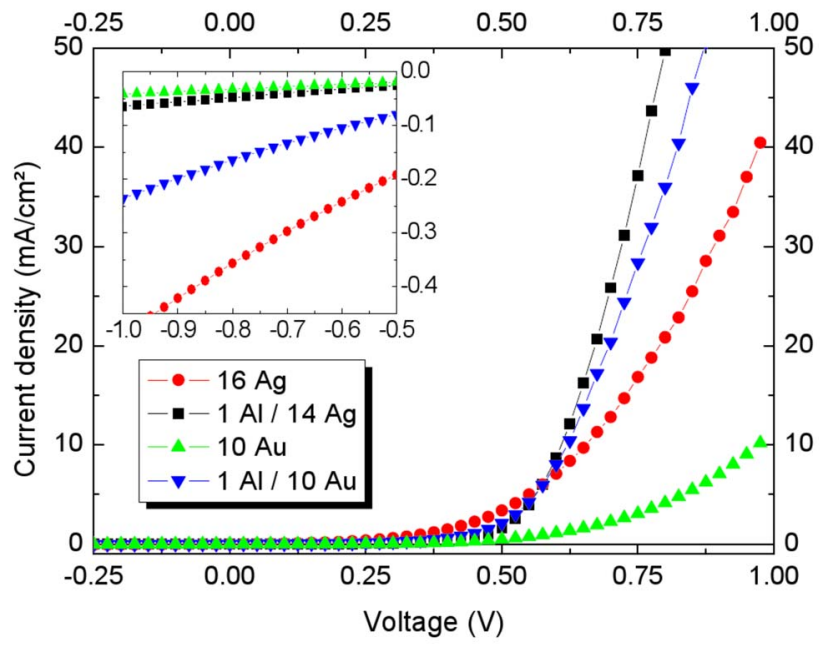

FIG. 3. (Color online) $J(V)$-dark characteristics under illumination of different solar cells with top contacts of (I) $16 \mathrm{~nm} \mathrm{Ag}$ (circles), (II) $1 \mathrm{~nm} \mathrm{Al} / 14$ $\mathrm{nm} \mathrm{Ag}$ (squares), (III) $10 \mathrm{~nm} \mathrm{Au}$ (triangles), and (IV) $1 \mathrm{~nm} \mathrm{Al} / 10 \mathrm{~nm} \mathrm{Au}$ (upside-down triangles). Inset: magnification of the voltage range of -1 to $-0.5 \mathrm{~V}$.

$\mathrm{eV}$ for $\mathrm{Au},{ }^{22}$ the energetical barrier for the charge carriers seems to be the same for both materials. The omission of the $1 \mathrm{~nm} \mathrm{Al}$ in solar cells (I) and (III) leads to reduced $V_{\text {OC }}(0.06$ $\mathrm{V}$ for $\mathrm{Ag}$ and $0.01 \mathrm{~V}$ for $\mathrm{Au}$ ), suggesting that the presence of, or chemical reactions with, $\mathrm{Al}$ at the interface of metal/ BPhen modifies the energetical barrier and the energy level alignment. It remains to be studied if $\mathrm{Al}$ indeed reacts with the BPhen or if $\mathrm{Al}$ diffuses into the molecular layer and leads to a doping effect. At the same time, remaining voids between BPhen and the metal contact are a prominent feature of samples without Al. This may lead to high local electron densities of SM-OSC under operation, resulting in a counterfield that increases the energy barrier for electrons to be injected from BPhen to the metal electrode. ${ }^{23}$

The short-circuit current densities $J_{\mathrm{SC}}$ are in the same order of magnitude, with Ag-containing metal contacts having higher transmission and leading to higher photocurrents. The presence of Al leads to reduced currents for both Agand Au-type electrodes, owing to the optical properties of Al.

The decisive influence on the SM-OSC efficiency originates from the differences of fill factor $(\mathrm{FF})$. The addition of $1 \mathrm{~nm} \mathrm{Al}$ to the stack leads to significant increases in FF, from $41 \%$ to $56 \%$ for the Ag-containing solar cells (I) and (II), and from $32 \%$ to $53 \%$ for the Au-containing solar cells (III) and (IV). In the $J(V)$-curves this is reflected in the S-kinks visible for the contacts consisting of only $\mathrm{Ag}$ and $\mathrm{Au}$, respectively. At the same time, the slope of the $J(V)$ for increasing positive voltages suggests that the series resistance $R_{S}$ is lowered significantly upon addition of $1 \mathrm{~nm} \mathrm{Al}$ as an interlayer.

The development of FF and $R_{S}$ is attributed to a direct influence of the morphology, as described below. The clusters, blind alleys, and isolated islands illustrated in the SEM and AFM micrographs hinder efficient extraction of photogenerated charge carriers. This results in the buildup of a counterfield, an energetical barrier represented by the S-kink. Since the electron extraction is slowed, higher recombination of excitons and dissociated charge carriers occurs, which ultimately limits solar cell performance.

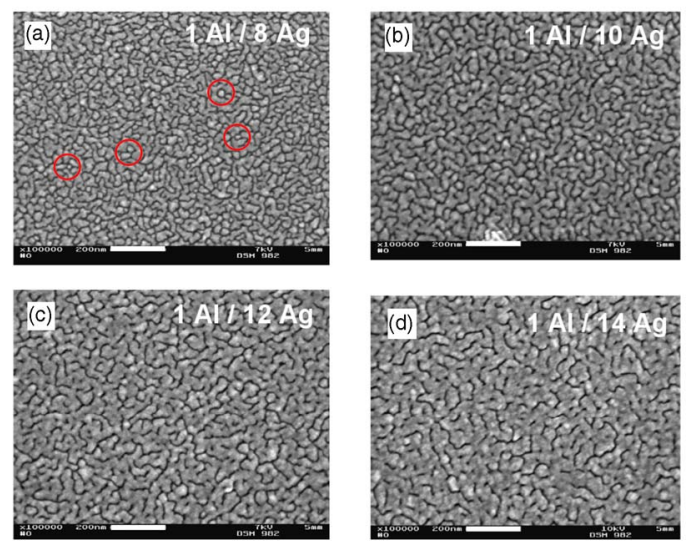

FIG. 4. (Color online) SEM micrographs of solar cell stacks with $1 \mathrm{~nm} \mathrm{Al}$ and (a) $8 \mathrm{~nm}$, (b) $10 \mathrm{~nm}$, (c) $12 \mathrm{~nm}$, and (d) $14 \mathrm{~nm} \mathrm{Ag} \mathrm{top} \mathrm{contact} \mathrm{layers.}$ The white scale bar represents $200 \mathrm{~nm}$. The circles in (a) highlight examples of isolated clusters. With increasing Ag thickness, the number of islands decreases and a closed layer begins to form.

\section{B. Morphological studies}

Ag thin films are optically interesting due to high transmittance in the visible range of the spectrum. Closed layers also exhibit high conductivity. Evaporation of thin metal films to form stable, continuous, and level surfaces is a challenging task. Obtaining a suitable morphology with low roughness depends on a variety of factors, e.g., temperature, evaporation rate, ${ }^{24}$ solvent treatment, ${ }^{25}$ substrate, ${ }^{25,26}$ surfactants, ${ }^{27-29}$ layer thickness, ${ }^{30}$ and even the partial pressure of gases which might be present during evaporation. ${ }^{31}$ For application in optoelectronic devices, continuous films are required. Previous experiments showed that the coalescence threshold of silver evaporated under the conditions described above at a rate of $\approx 0.3 \AA / \mathrm{s}$ is between 14 and $15 \mathrm{~nm}$. Operational SM-OSCs are obtained at $15 \mathrm{~nm}$ thickness, ${ }^{16}$ but low $\mathrm{FF}<40 \%$ hints at islandlike morphology with bad charge extraction.

In contrast, solar cell electrodes with nanometer-thin $\mathrm{Al}$ layers between the organic materials and Ag show considerably better morphology and allow to study the coalescence of Ag which occurs with increasing thickness. This is illustrated in Fig. 4, where SEM micrographs of samples with $1 \mathrm{~nm} \mathrm{Al}$ and different Ag thicknesses are shown. The samples consist of complete solar cell material stacks so that the electrodes represent realistic conditions and can be used for operational devices. $^{32}$

Figures 4(a)-4(d) show SEM images of samples with metal layers having increasing Ag thicknesses deposited on complete SM-OSC material stacks. It is clearly visible that Fig. 4(a) (1 nm Al/8 nm Ag) contains a large amount of isolated islands, some of which have been marked with circles. These islands are not part of a charge-carrier percolation network, and charge extraction is hindered with this type of contact layer. For devices employing this metal contact, it is possible to observe a photovoltaic effect, but since the photocurrent is in the microampere range and $\mathrm{FF}<25 \%$, this type of electrical contact is insufficient for efficiently operational devices. When increasing the Ag thickness, Fig. 4(b) still exhibits islands, but the surface coverage has in- 

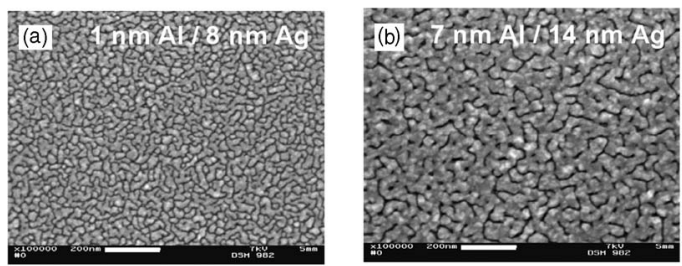

FIG. 5. SEM micrographs of solar cell stacks with (a) $1 \mathrm{~nm} \mathrm{Al} / 8 \mathrm{~nm} \mathrm{Ag}$ and (b) $7 \mathrm{~nm} \mathrm{Al} / 14 \mathrm{~nm} \mathrm{Ag} \mathrm{top} \mathrm{contact} \mathrm{layers.} \mathrm{The} \mathrm{white} \mathrm{scale} \mathrm{bar} \mathrm{represents} 200$ $\mathrm{nm}$. The formation of more charge carrier percolation pathways and the tendency toward a closed layer with increasing contact thickness is visible.

creased and the $\mathrm{Ag}$ starts to form interconnected networks. 1 $\mathrm{nm} \mathrm{Al} / 12 \mathrm{~nm} \mathrm{Ag}$, as shown in Fig. 4(c), is sufficient for electron percolation networks and leads to $\mathrm{FF}>50 \%$ with $\eta \approx 2 \%$ (data not shown here). Optimal SM-OSC performance is achieved for $1 \mathrm{~nm} \mathrm{Al} / 14 \mathrm{~nm} \mathrm{Ag}$ with $J_{\mathrm{SC}}$ $=7.02 \mathrm{~mA} / \mathrm{cm}^{2}, \quad V_{\mathrm{OC}}=0.529 \mathrm{~V}, \quad \mathrm{FF}=56.21 \%$, and $\eta$ $=2.09 \%$. When going to thicker $\mathrm{Ag}$ or $\mathrm{Al}$ layers, the increasing absorption and reflection of the metal layers lead to lower solar cell performance.

The effect of layer thickness on the morphological development is shown in Figs. 5(a) and 5(b), where the thinnest $(1 \mathrm{~nm} \mathrm{Al} / 8 \mathrm{~nm} \mathrm{Ag}$ ) and thickest $(7 \mathrm{~nm} \mathrm{Al} / 14 \mathrm{~nm} \mathrm{Ag})$ multilayer metal contacts are shown for comparison, illustrating the formation of a continuous layer. It has to be noted, however, that $7 \mathrm{~nm} \mathrm{Al} / 14 \mathrm{~nm} \mathrm{Ag}$ leads to a lower light transmission and limits photon absorption in the SM-OSC, ultimately limiting device performance. Even for this structure, the total metal thickness being $21 \mathrm{~nm}$, one still observes voids in the network. However, further increasing the layer thickness is expected to be counterproductive since the light transmission would be too low.

The surface-modifying effect of Al underlayers can be observed for Au layers as well, as shown in the SEM images [Figs. 6(a) to 6(d)]. For Au layers of only $6 \mathrm{~nm}$ thickness, cracks and voids are observed between islands of Au which isolate large areas from the percolation network. Upon addition of $1 \mathrm{~nm} \mathrm{Al}$ underlayer, the surface coverage is improved and the longer, larger cracks are replaced by small voids, as seen in Fig. 6(b). A similar effect is observed for thicker layers, as shown in Fig. 6(c) $(16 \mathrm{~nm} \mathrm{Au})$ and Fig. 6(d) $(1 \mathrm{~nm}$
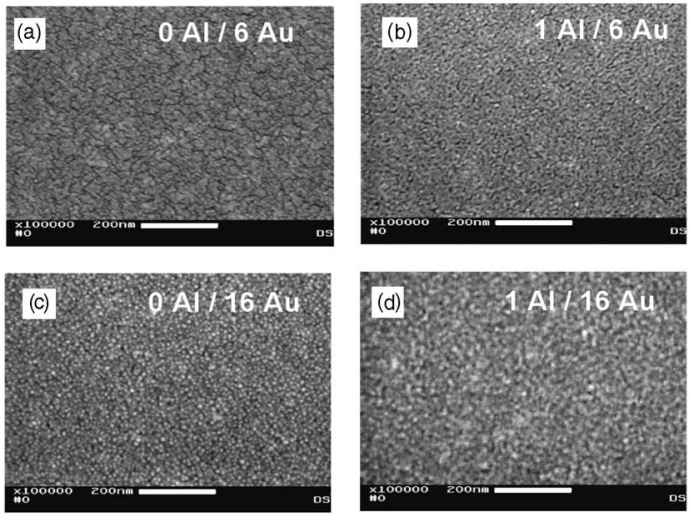

FIG. 6. SEM micrographs of solar cell stacks with (a) $6 \mathrm{~nm} \mathrm{Au,} \mathrm{(b)} 1 \mathrm{~nm}$ $\mathrm{Al} / 6 \mathrm{~nm} \mathrm{Au}$, (c) $16 \mathrm{~nm} \mathrm{Au}$, and (d) $1 \mathrm{~nm} \mathrm{Al} / 16 \mathrm{~nm}$ Au top contact layers. The white scale bar represents $200 \mathrm{~nm}$.
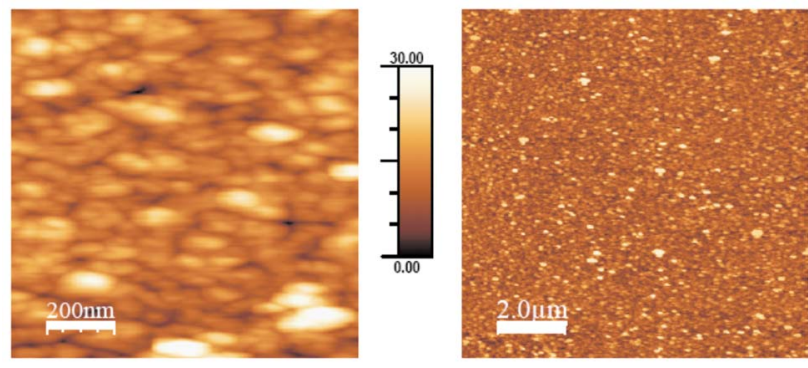

FIG. 7. (Color online) AFM micrographs of $14 \mathrm{~nm}$ Ag evaporated on glass. The $z$-scalebar is $30 \mathrm{~nm}$. The white scale bar represents $200 \mathrm{~nm}$ (left) and $2 \mu \mathrm{m}$ (right), respectively.

$\mathrm{Al} / 16 \mathrm{~nm} \mathrm{Au}) .16 \mathrm{~nm} \mathrm{Au}$ is sufficient for conductive samples, but clusters of $\approx 10 \mathrm{~nm}$ diameter are still visible. This changes when using an $\mathrm{Al}$ interlayer. Instead of single grains, larger connected areas with lower roughness are observed. In all cases, the insertion of this interlayer between BPhen and Au leads to completely different morphologies, analogous to Ag samples.

Surface morphology and root mean square roughness

$$
R_{\mathrm{rms}}=\sqrt{\frac{1}{M N} \sum_{m=1}^{M} \sum_{n=1}^{N}\left[z\left(x_{m}, y_{n}\right)-\langle z\rangle\right]^{2}}
$$

of samples containing $\mathrm{Al} / \mathrm{Ag}$ are studied by AFM. Examples are shown in Fig. $7(14 \mathrm{~nm} \mathrm{Ag})$ and Fig. $8(1 \mathrm{~nm} \mathrm{Al} / 14 \mathrm{~nm}$ $\mathrm{Ag}$ ) (note the different scalebars representing 30 and $20 \mathrm{~nm}$, respectively). Both samples were evaporated directly onto glass without underlying organic layers. $14 \mathrm{~nm} \mathrm{Ag}$ yields $R_{\mathrm{rms}} \approx 3.6-5 \mathrm{~nm}$, while $1 \mathrm{~nm} \mathrm{Al}$ underneath the Ag lowers $R_{S}$ to $\approx 2.3-2.6 \mathrm{~nm}$. This confirms that $\mathrm{Ag}$ grows in large islands and clusters even at layer thicknesses of $>10 \mathrm{~nm}$ when no surfactant is used; the interconnections between the clusters are relatively thin since the bulk of the deposited mass is concentrated in the clusters. Remarkably, thinner multilayers, e.g., the $1 \mathrm{Al} / 12 \mathrm{Ag}$ mentioned above, tend to form smoother interpenetrating networks with better electrical properties compared to thicker $(14 \mathrm{~nm})$ layers of pure noble metal.

It is currently not clear which mechanism leads to the smoothening effect. Photoelectron spectroscopy experiments of $\mathrm{Ag}, \mathrm{Cu}$, and $\mathrm{Au}$ on pentacene ${ }^{33}$ suggest that pentacene floats in the metal layers, always forming an organic monolayer on top of the metal which leads to reduced surface
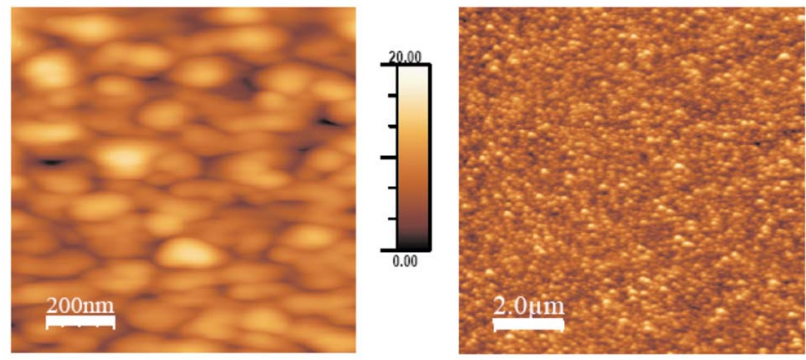

FIG. 8. (Color online) AFM micrographs of $1 \mathrm{~nm} \mathrm{Al} / 14 \mathrm{~nm} \mathrm{Ag} \mathrm{evaporated}$ on glass. The $z$-scalebar is $20 \mathrm{~nm}$. The white scale bar represents $200 \mathrm{~nm}$ (left) and $2 \mu \mathrm{m}$ (right), respectively. 
energy. In the current case, it is conceivable that BPhen molecules float within a pure Ag layer and influence the structure formation in such a way that island growth is energetically favorable due to molecules covering the voids. If a thin $\mathrm{Al}$ layer is present, it may react with the BPhen molecules and pin them in place, leading to a closed metal layer which has a smaller surface compared to porous and isolated clusters. Since metal diffusion into the underlying BPhen can also be expected, ${ }^{34}$ especially for noble Ag, further investigation of these competing processes might help to understand the role of the Al surfactant.

\section{CONCLUSION}

We have investigated thin semitransparent metal contacts for organic solar cells. The data presented illustrate the formation of the surface morphology of combinations of thin metal multilayers on organic materials. It is shown that $\mathrm{Ag}$ grows in rough surfaces in the form of single clusters which only start to coalesce at thicknesses of $15-16 \mathrm{~nm}$, which is more than previously assumed. The presence of $1 \mathrm{~nm} \mathrm{Al}$ as a surface-modifying agent between organic materials and $\mathrm{Ag}$ results in a flatter, smoother morphology, resembling a continuous layer with residual voids and a much lower surface roughness.

SEM images show the transition of an $\mathrm{Al} / \mathrm{Ag}$ multilayer system evaporated onto organic material from isolated islands to a fully interconnected network with increasing $\mathrm{Ag}$ thickness. The high conductivity and light transmission make this network useful for optoelectronic devices. OSCs are shown which underline the role of an ultrathin Al layer as a surface-modifying agent. The presence of Al leads to a slightly higher $V_{\mathrm{OC}}$ and a strongly improved FF, which increases SM-OSC performance by over 50\%, despite lower photocurrents caused by the slightly lower transmission. The optimal solar cell structure employs a combination of $1 \mathrm{~nm}$ Al for improved morphology of the metal contact and $14 \mathrm{~nm}$ Ag for improved electrical and optical properties and reaches promising efficiencies of $2.09 \%$, which has the potential to be increased further by optimization of solar cell stack and used materials.

\section{ACKNOWLEDGMENTS}

The current work was supported by the Bundesministerium für Bildung und Forschung in the framework of the InnoProfile project (Contract No. 03IP602). We thank Ellen Kern from the electrochemistry group of Technical University Dresden for assistance with SEM measurements.
${ }^{1}$ C. W. Tang, Appl. Phys. Lett. 48, 183 (1986).

${ }^{2}$ D. Meissner and J. Rostalski, Synth. Met. 121, 1551 (2001).

${ }^{3}$ K. Walzer, B. Maennig, M. Pfeiffer, and K. Leo, Chem. Rev. (Washington, D.C.) 107,1233 (2007)

${ }^{4}$ J. Drechsel, B. Maennig, F. Kozlowski, M. Pfeiffer, K. Leo, and H. Hoppe, Appl. Phys. Lett. 86, 244102 (2005).

${ }^{5}$ J. Xue, S. Uchida, B. P. Rand, and S. R. Forrest, Appl. Phys. Lett. 85, 5757 (2004).

${ }^{6}$ J. Y. Kim, K. Lee, N. E. Coates, D. Moses, T.-Q. Nguyen, M. Dante, and A. J. Heeger, Science 317, 222 (2007).

${ }^{7}$ S. Guenes, H. Neugebauer, and N. S. Sariciftci, Chem. Rev. (Washington, D.C.) 107,1324 (2007).

${ }^{8}$ H. Hoppe and N. S. Sariciftci, J. Mater. Chem. 19, 1924 (2004).

${ }^{9}$ Z. Chen, B. Cotterell, W. Wang, E. Guenther, and S.-J. Chua, Thin Solid Films 394, 201 (2001).

${ }^{10}$ K. Schulze, B. Maennig, K. Leo, Y. Tomita, C. May, E. Brier, E. Reinold, and P. Baeuerle, Appl. Phys. Lett. 91, 073521 (2007).

${ }^{11}$ J. van de Lagemaat, T. M. Barnes, G. Rumbles, S. E. Shaneen, T. J. Coutts, C. Weeks, I. Levitsky, J. Peltola, and P. Glatkowsky, Appl. Phys. Lett. 88, 233503 (2006).

${ }^{12}$ M. W. Rowell, M. A. Topinka, M. D. McGehee, H.-J. Prall, G. Dennler, N. S. Sariciftci, L. Hu, and G. Gruner, Appl. Phys. Lett. 88, 233506 (2006).

${ }^{13}$ J. Meiss, C. L. Uhrich, K. Fehse, S. Pfuetzner, M. K. Riede, and K. Leo, Proc. SPIE 7002, 700210 (2008).

${ }^{14}$ B. Zimmermann, M. Glatthaar, M. Niggemann, M. K. Riede, A. Hinsch, and A. Gombert, Sol. Energy Mater. Sol. Cells 91, 374 (2007).

${ }^{15}$ T. Oyamada, Y. Sugawara, Y. Terao, H. Sasabe, and C. Adachi, Jpn. J. Appl. Phys., Part 1 46, 1734 (2007).

${ }^{16}$ J. Meiss, N. Allinger, M. K. Riede, and K. Leo, Appl. Phys. Lett. 93, 103311 (2008).

${ }^{17}$ R. B. Pode, C. J. Lee, D. G. Moon, and J. I. Han, Appl. Phys. Lett. 84, 4614 (2004).

${ }^{18}$ J. Wu, H. A. Becerril, Z. Bao, Z. Liu, Y. Chen, and P. Peumans, Appl. Phys. Lett. 92, 263302 (2008).

${ }^{19}$ J.-Y. Lee, S. T. Connor, Y. Cui, and P. Peumans, Nano Lett. 8, 689 (2008).

${ }^{20}$ Used for better processibility, comparable in performance to the commonly available 2,3,5,6-tetrafluoro-7,7,8,8-tetracyanoquinodimethane (F4TCNQ).

${ }^{21}$ B. O'Connor, K. H. An, K. P. Pipe, Y. Zhao, and M. Shtein, Appl. Phys. Lett. 89, 233502 (2006).

${ }^{22}$ H. B. Michaelson, J. Appl. Phys. 48, 4729 (1977).

${ }^{23}$ D. Gupta, M. Bag, and K. K. Narayan, Appl. Phys. Lett. 92, 093301 (2008).

${ }^{24}$ R. S. Sennett and G. D. Scott, J. Opt. Soc. Am. 40, 203 (1950).

${ }^{25}$ S. E. Roark and K. L. Rowlen, Anal. Chem. 66, 261 (1994).

${ }^{26}$ A. E. Duerr, F. Schreiber, M. Kelsch, H. D. Carstanjen, and H. Dosch, Adv. Mater. (Weinheim, Ger.) 14, 961 (2002).

${ }^{27}$ J. Camarero, J. Ferron, V. Cros, L. Gomez, A. L. Vazquez de Parga, J. M. Gallego, J. E. Prieto, J. J. de Miguel, and R. Miranda, Phys. Rev. Lett. 81, 850 (1998).

${ }^{28}$ G. Rosenfeld, R. Servaty, C. Teichert, B. Poelsema, and G. Comsa, Phys. Rev. Lett. 71, 895 (1993).

${ }^{29}$ F. K. LeGoues, B. D. Silverman, and P. S. Ho, J. Vac. Sci. Technol. A 6, 2200 (1988).

${ }^{30}$ C. G. Granqvist, Sol. Energy Mater. Sol. Cells 91, 1529 (2007).

${ }^{31}$ J. M. Riveiro, P. S. Normile, J. P. Andres, J. A. Gonzalez, J. A. De Toro, T. Munoz, and P. Muniz, Appl. Phys. Lett. 89, 201902 (2006).

${ }^{32}$ J. Meiss, M. K. Riede, and K. Leo, Appl. Phys. Lett. 94, 013303 (2009).

${ }^{33}$ B. Jaeckel, J. B. Sambur, and B. A. Parkinson, Langmuir 23, 11366 (2007).

${ }^{34}$ N. J. Watkins, L. Yan, and Y. Gao, Appl. Phys. Lett. 80, 4384 (2002). 